\title{
Direito Civil Alemão no Brasil do Século XiX: Teixeira de Freitas e a Escola Histórica Alemã
}

\section{German Civil Law in 19th Century Brazil: Teixeira de Freitas and the Historical School of Law}

\section{Derecho Civil Alemán en el Brasil del Siglo xix: Teixeira de Freitas y la Escuela Histórica Alemana}

\author{
Gabriela Back Lombardi* \\ Fernanda Cristina Covolan ${ }^{* *}$
}

1 Introdução. 2 A Escola Histórica Alemã e Jurisprudência dos Conceitos. 3 Cultura Jurídica Brasileira do século XIX - Augusto Teixeira de Freitas. 4 Considerações Finais. Referências.

\section{RESUMO}

Objetivo: A partir da chave de compreensão proporcionada pelo conceito de tradução cultural, a proposta da presente investigação centrou-se em dimensionar a influência e circulação das ideias advindas da Escola Histórica Alemã e da Jurisprudência dos Conceitos no desenvolver intelectual do jurista Augusto Teixeira de Freitas, cujo trabalho deu forma ao direito pátrio em processo de modernização no século XIX.

Metodologia: A pesquisa utilizou-se de método empírico e dedutivo, partindo da análise de fontes primárias consistentes em publicações do autor à época, aliada à revisão bibliográfica da historiografia jurídica sobre o século XIX no que pertinente.

\footnotetext{
Mestranda em Direito na Universidade Federal do Paraná, Graduada em Direito pela Pontifícia Universidade Católica do Paraná - Campus Maringá, com período de mobilidade acadêmica na Universidade de Lisboa como bolsista do Programa Santander Universidades. Curitiba - PR - BR. Email: <gabriela.blombardi@gmail.com>. http://orcid.org/0000-0001-7581-0233

"* Doutora em Direito Político e Econômico (Mackenzie-SP); Coordenadora do Grupo de Pesquisa Empírica em Direito (Unasp-HT); Coordenadora do Curso de Direito do Unasp HT; Professora titular de História do Direito - Unasp. Engenheiro Coelho - SP - BR. E-mail: <fernandacovolan@hotmail.com>.http://orcid.org/0000-0002-6993-9054
} 
Resultados: As tendências teóricas germânicas foram absorvidas no Brasil a partir da circulação dos modelos jurídicos advindos da Europa. A análise da produção jurídica de Teixeira de Freitas leva à conclusão de que o autor se colocou, nesse contexto, entre a fidelidade à tradição jurídica da praxística portuguesa e as contribuições inovadoras do iluminismo. A influência exercida em sua obra e trajetória pela Escola Histórica Alemã e no posterior conceitualismo sistematizador, por sua vez, é inegável, de modo que o autor empregou a conjugação de diversas fontes teóricas em favor da modernização do direito brasileiro.

Contribuições: Pensar a circulação das tendências teóricas num caráter transnacional, a partir do conceito de tradução cultural, possibilita que os processos de formação de normatividade sejam entendidos de forma nuançada e complexificada, considerando as ressignificações que surgem em contextos específicos. Demonstra-se, assim, a essencialidade do estudo histórico-jurídico para questionar de forma crítica os pressupostos inconscientes das disciplinas dogmáticas, revelando a historicidade por detrás das soluções propostas.

Palavras-chave: Escola Histórica alemã; cultura jurídica brasileira; Augusto Teixeira de Freitas.

\section{ABSTRACT}

Objective: From the understanding provided by the concept of cultural translation, the proposal of the present investigation focused on dimensioning the influence and circulation of ideas from the German Historical School and from the Jurisprudence of Concepts in the intellectual development of the jurist Augusto Teixeira de Freitas, whose work shaped the modern brazilian law.

Methodology: This research used an empirical and deductive method, starting from the analysis of primary sources consistent in the author's publications at the time, combined with a bibliographic review of the legal historiography on the nineteenth century, as pertinent.

Results: German theoretical trends were absorbed in Brazil in the context of the circulation of legal models from Europe. The analysis of Teixeira de Freitas' legal production leads to the conclusion that the author placed himself, in this context, between fidelity to the legal tradition of Portuguese praxis and the innovative contributions of the Enlightenment. The influence exerted on his work and trajectory by the German Historical School and the subsequent systematizing conceptualism, in turn, is undeniable, so that the author used a combination of different theoretical sources in favor of the modernization of Brazilian law. 
Contributions: To think about the circulation of theoretical trends in a transnational character, based on the concept of cultural translation, allows the processes of normativity formation to be understood in a nuanced and complex way, considering the resignifications that arises in specific contexts. This demonstrates, therefore, the essentiality of the historical-legal study to critically question the unconscious assumptions of dogmatic disciplines, revealing the historicity behind the proposed solutions.

Keywords: German Historical School; brazilian legal culture; Augusto Teixeira de Freitas.

\section{RESUMEN}

Objetivo: Partiendo de la clave de entendimiento que brinda el concepto de traducción cultural, la propuesta de la presente investigación se centró en dimensionar la influencia y circulación de ideas surgidas de la Escuela Histórica Alemana y la Jurisprudencia de Conceptos en el desarrollo intelectual del jurista Augusto Teixeira de Freitas, cuya obra dio forma a la legislación nacional en pleno proceso de modernización en el siglo XIX.

Metodología: La investigación utilizó un método empírico y deductivo, partiendo del análisis de fuentes primarias acordes con las publicaciones del autor en ese momento, combinado con una revisión bibliográfica de la historiografía jurídica del siglo XIX, según corresponda.

Resultados: Las tendencias teóricas alemanas fueron absorbidas en Brasil a partir de la circulación de modelos legales provenientes de Europa. El análisis de la producción jurídica de Teixeira de Freitas lleva a la conclusión de que el autor se situó, en este contexto, entre la fidelidad a la tradición jurídica de la praxis portuguesa y los aportes innovadores de la Ilustración. La influencia ejercida en su obra y trayectoria por la Escuela Histórica Alemana y el posterior conceptualismo sistematizador, a su vez, es innegable, por lo que el autor utilizó una combinación de diferentes fuentes teóricas a favor de la modernización del derecho brasileño.

Contribuciones: Pensar en la circulación de corrientes teóricas de carácter transnacional, a partir del concepto de traducción cultural, permite comprender de manera matizada y compleja los procesos de formación de normatividad, considerando las resignificaciones que surgen en contextos específicos. Esto demuestra, por tanto, la esencialidad del estudio histórico-jurídico para cuestionar críticamente los supuestos inconscientes de las disciplinas dogmáticas, revelando la historicidad detrás de las soluciones propuestas. 
Palabras clave: Escuela Histórica Alemana; cultura jurídica brasileña; Augusto Teixeira de Freitas.

\section{INTRODUÇÃO}

Nestas primeiras linhas introdutórias, precisamos não apenas permitir ao leitor que compreenda o caminho proposto nesta investigação, mas também elucidar o valor do estudo histórico-jurídico a partir das lentes do momento presente, sem esquecer de dar ao leitor acesso aos subsídios teórico-metodológicos que permitiram a realização da própria investigação. Apresentamos, portanto, um panorama breve, mas aprofundado, que justifica a perspectiva adotada, com a intenção de tornar a leitura mais afável.

O papel do estudo histórico-jurídico para compreensão das estruturas teóricas do direito contemporâneo não é pequeno. O exercício de alteridade que o historiador deve levar a feito em sua pesquisa é essencial para revelar aspectos subjacentes à teoria do direito atual, que, apesar de nos parecer neutra ou natural, é historicamente construída.

O campo jurídico ${ }^{1}$, assim, é sempre referencial: responde aos fatos da vida que se impõem e oferece soluções contingenciais à tal realidade (HESPANHA, 2017, p. 13). Assim, questões que permeiam as preocupações do teórico do direito, como aquelas relacionadas à legitimidade dos agentes para dizer o direito, à hierarquia das fontes normativas, ao papel do Estado na construção da ordem jurídica etc., estão necessariamente vinculadas ao contexto de produção das respectivas ideias e instituições. Em resumo, o direito é feito em um lugar e tempo determinado, de modo que a dimensão local e temporal de sua produção não pode ser ignorada.

Abordar temas correntes da perspectiva da história do pensamento jurídico pode, nessa toada, contribuir para o estudo da teoria do direito ao privilegiar a dimensão temporal e local do direito, abrindo espaço para questionar os "lugares comuns recebidos sem uma adequada confirmação cultural” (GROSSI, 2007, p. 13). Dessa forma, adota-se a premissa que a compreensão dos institutos e dos conceitos jurídicos da atualidade não dispensa o estudo de seus lugares históricos, uma vez que são frutos das temporalidades e das localidades em que surgiram.

Munido da consciência quanto à essencialidade do estudo histórico para teoria do direito, este trabalho procurou desvelar aspectos importantes na formação da cultura jurídica brasileira no decorrer do século XIX. A partir da leitura do jurista baiano

\footnotetext{
${ }^{1}$ Utilizou-se, neste trabalho, a noção de campo jurídico formulada por Pierre Bourdieu, compreendido como lócus de concorrência pelo monopólio da produção cultural e simbólica reconhecida como legítima pela autoridade da enunciação. As práticas jurídicas, assim, são práticas também simbólicas, de modo que conferem sentidos discursivos próprios no campo jurídico. Nesse sentido, cf. (BOURDIEU, 2016, p. 217 ss.).
} 
Augusto Teixeira de Freitas, buscou-se identificar o alcance e o tom do influxo germanófilo sobre a construção do direito civil no Brasil Império. Acredita-se que tal esforço investigativo pode contribuir para entender que o universo jurídico não é um invólucro lacrado de disposições normativas, como somos tentados a acreditar, mas encontra-se em constante movimento, oferecendo diariamente novos desafios à teoria do direito contemporânea.

O recorte temporal proposto reflete a compreensão de que o século XIX foi palco da afirmação das estruturas modernas para se pensar o direito, o que possibilita a ponte com a teoria do direito contemporânea. A paulatina caminhada em direção ao monismo jurídico, à laicidade e ao individualismo, assim como a redução do fenômeno jurídico à estatalidade, advindas da emergência do Estado de Direito e da ideia de sua constituição, centralização e organização por meio da lei, levaram à construção de novos quadros para pensar o direito que são ainda a base cultural da formação do jurista moderno (GROSSI, 2005a, p. 32).

Além disso, se tais características da modernidade jurídica são hoje facilmente associadas ao direito público, os quadros estruturantes que lhe são constituintes adquirem especial importância quando se trata do direito privado, tendo em vista seu papel garantidor dos valores caros à emergente ordem burguesa liberal oitocentista (GROSSI, 2005b, p. 105). A presença de um ordenamento que garantisse as liberdades individuais, ainda que formalmente, e a propriedade privada colocava-se como condição para inclusão das nações emergentes na categoria civilizatória dos países centrais (PETIT, 2011, p. 25).

Nesse contexto, a problemática proposta por este estudo se centra em dimensionar a influência e circulação da tradição jurídico-intelectual germânica, como formadora do discurso científico-jurídico moderno, na construção da cultura jurídica brasileira no século XIX, lida a partir do jurista baiano Augusto Teixeira de Freitas. A tradição alemã é acessada por meio da compreensão das características fundamentais das duas principais linhagens teóricas do direito circulantes naquela altura: a Escola Histórica do Direito e a Jurisprudência dos Conceitos.

Dessa forma, o artigo trabalha com os influxos migratórios entre a cultura jurídica germânica e brasileira. $\mathrm{O}$ conceito de cultura jurídica, ao referir-se ao conjunto de padrões e significados circulantes em determinada época, permite acessar o direito de uma perspectiva interna, tomando-se o posto de observação outrora ocupado pelo próprio jurista (GROSSI, 2000, p. 16). De tal forma, mais do que se preocupar com alterações legislativas oficiais e contingências políticas específicas, o presente estudo ocupa-se do que pensavam os juristas do século XIX. Assim, compreender a reflexão jurídica de acordo com seus tempos e suas ferramentas de produção pode revelar além da técnica de um saber doutrinário especializado, desnudando a estrutura do próprio contexto em que se insere determinada tradição (FONSECA, 2011, p. 342). Mais do 
que isso, tomar o pensamento como objeto de estudo pode desvelar a construção da legitimidade por trás do "dizer o direito".

Teixeira de Freitas foi escolhido como figura central de tal análise na medida em que sua Consolidação das Leis Civis dá forma ao direito pátrio modernizante, assim como é emblemática do contexto de transição às formas modernas de produzir o direito. Ao organizar o complexo quadro de fontes do direito civil brasileiro oitocentista, não necessariamente refletidos por dados legislativos, o "jurisconsulto do império" foi responsável por nortear as elaborações jurídicas feitas a seguir, inclusive na atualidade.

Não nos enganemos. Ainda que a codificação civil tenha passado por uma reforma significativa já no século XXI, as estruturas fundantes do pensamento jurídico, que escapam à ordenação das relações privadas, mantêm raízes no pensamento de Freitas e no próprio ideal de modernização jurídica compartilhado pelos juristas do Império, como este trabalho demonstra.

A estrutura do artigo é composta, além dessa breve introdução e de uma conclusão final, por dois trechos que enfatizam, respectivamente, os aspectos centrais da cultura jurídica alemã e a recepção de tais ideias no Brasil do século XIX. Dessa forma, no primeiro trecho, buscou-se delinear as linhas estruturantes do pensamento jurídico do romantismo alemão na figura da Escola Histórica do Direito e da Jurisprudência dos Conceitos, em especial a partir do pensamento de Friedrich Carl von Savigny e de Georg Friedrich Puchta.

Já no segundo trecho, o esforço teórico voltou-se à compreensão, em especial, da formação e da modernização do direito civil no Brasil oitocentista por meio da identificação, em Teixeira de Freitas, de traços advindos do historicismo e do conceitualismo alemão e incorporados à cultura jurídica brasileira. A busca de tais traços, entretanto, tem em conta a necessária ressignificação teórica das proposições europeias no contexto brasileiro pós-independência, cujo âmbito normativo, como bem aponta Fonseca (2006b, p. 340-344), revela a tensão entre a vigência de legislações do período colonial e de tendências modernizantes num Estado que se pretendia liberal, mas seguia sustentado por estruturas oligárquicas e autoritárias.

\section{A ESCOLA HISTÓRICA ALEMÃ E A JURISPRUDÊNCIA DOS CONCEITOS}

Procurar entender a formação do campo jurídico brasileiro no século XIX, assim como as implicações de tais debates intelectuais na estruturação da teoria do direito moderna, não pode dispensar de uma metodologia histórico-comparada. Nosso direito civil não surgiu no vácuo, mas respondeu às contingências políticas, sociais e ideológicas de sua época de formação. Talvez a principal delas, que justifica o estudo comparativo, resida na constatação de que a teoria civilística moderna se estruturou em grande 
medida a partir de uma série de modelos de codificação advindos da Europa (PETIT, 2011, p. 4).

Assim, a circulação dessa cultura do direito privado codificado, com intenções de validade supranacionais, ordenou as próprias realidades nacionais e funcionou sutilmente como instrumento de dominação e construção das identidades nacionais com a pretensão de alçar as nações ao status civilizatório (PETIT, 2011, p. 14-21). Daí a importância de procurar elementos que conectem e conformem as diferentes culturas jurídicas por meio do direito civil, bem como revelem a nacionalização da teoria privatista (e suas respectivas cargas ideológicas) no Brasil oitocentista.

A partir dessa perspectiva, considerando o panorama histórico das correntes interpretativas e metodológico-teóricas do direito, a Escola Histórica Alemã e a Jurisprudência dos Conceitos, situadas temporalmente entre o final do século XVIII e o início do século XIX, exerceram um papel fundamental. Talvez, para um pesquisador de áreas mais dogmáticas, possa parecer estranha essa afirmação, na medida em que referências a tais ligações tenham se esmaecido na literatura jurídica, mas é preciso compreender que o lugar histórico da intelectualidade alemã na definição de conceitos jurídicos correntes é central. Tome-se como exemplo a conhecida discussão sobre o conceito da posse entre Rudolf von Ihering e Friedrich Carl von Savigny, que constitui capítulo introdutório de grande parte das disciplinas de Direitos Reais nas faculdades de direito e nas doutrinas jurídicas, das mais clássicas às mais atuais² (SAVIGNY, 1865; IHERING, 2004). Não há como estudar teoria da posse sem compreender o debate dos dois grandes teóricos romanistas, travado em grande parte no contexto oitocentista que ora se busca descortinar.

O contexto de surgimento da tradição historicista do direito na Alemanha está ligado à tradição do usus modernus pandectarum em território alemão, concebida ainda na primeira modernidade. Essa escola de pensamento jurídico se desenvolveu a partir do séc. XVI, quando o direito romano foi recepcionado de forma oficial no Império Romano-Germânico. A recepção oficializada, derivada da pretensão do imperador de construir uma continuidade entre o Império Romano e o Germano-Alemão medieval, demandou a conciliação entre as normas de direito romano e a complexa realidade da época. O Corpus Iuris Civilis, compilado cerca de mil anos antes, não possuía respostas prontas para os dilemas enfrentados pelo Império no início da época moderna. $O$ enfrentamento de tais questões pelos juristas do período, assim, deu origem ao que se convencionou denominar usus modernus pandectarum: trata-se de tradição jurídica que trabalhou com a "prática atualizada do direito romano", responsável por assimilá-lo à ciência do direito alemã (WIEACKER, 1967, p. 227). A abertura à prática possibilitou

\footnotetext{
${ }^{2}$ É o caso, por exemplo, das obras doutrinárias de Orlando Gomes e Melim Namem Chalhub (GOMES, 2012, p. 29; CHALHUB, 2013, p. 37).
} 
uma relação mais livre com o próprio texto, de modo que seu conteúdo passou a ser apreendido pelas lentes da realidade.

Mais tarde, a tradição da Escola Histórica deu bases ao que se denominou chamar de positivismo jurídico ${ }^{3}$, estabelecendo o embrião da perspectiva formalista ${ }^{4}$ segundo a qual o direito é expressão da vontade humana, e não um dado apriorístico existente na natureza. Inicia-se paulatinamente o processo de separação entre o campo jurídico e o campo da moral (HESPANHA, 2017, p. 399).

Nesse contexto, partindo do estudo dos usos modernos do direito romano ${ }^{5}$, a proposta metodológica desenvolvida pela Escola Histórica Alemã fundamentou-se, em linhas gerais, na consciência popular, na história e nas tradições de um povo como fontes do verdadeiro direito positivo. Assim, "positivo era o direito plasmado na vida, nas instituições ou num espírito do povo que se objetivava nas formas quotidianas observáveis de viver o direito" (STAUT JUNIOR, 2015, p. 1353). A crítica ao direito natural e, em certa medida, também ao jusracionalismo-iluminista ${ }^{6}$, foi realizada, então, na contraposição e na valorização do direito doutrinal e costumeiro, como representantes da tradição, aliando a visão do jurídico a um subjetivismo ético e contextual (SCHIAVELLO, 2008, p. 59).

O historicismo sustentou, nessa toada, a inexistência de caracteres fundamentais e imutáveis do homem, ressaltando as diferenças resultantes dos respectivos contextos. Em suma, opôs ao racionalismo dos jusnaturalistas oitocentistas o elemento passional que constituiria o motor da humanidade, em conjunto com a tradição (BOBBIO, 1995, p. 49).

Por óbvio, na experiência jurídica brasileira, a permanência das fontes jurídicas de procedência medieval, com forte participação do direito canônico na gestão de parte

${ }^{3}$ Para já, importa destacar a inexistência de um conceito monista do que seria tal positivismo jurídico: existem positivismos, no plural, a revelar uma amplitude de teses, nem sempre compatíveis entre si, que buscam explicar o que é o Direito a partir dessa perspectiva (SCHIAVELLO, 2008, p. 61-62).

${ }^{4}$ Norberto Bobbio afirma que “'escola histórica' e 'positivismo jurídico' não são a mesma coisa; contudo a primeira preparou o segundo por meio de sua crítica radical do direito natural” (BOBBIO, 1995. p. 45). Com essa clarificação, evita-se pensar de forma anacrônica acerca da formulação do só depois denominado positivismo jurídico.

${ }^{5}$ A título de exemplo, uma das obras mais célebres do principal representante da tradição jurídica alemã no séc., XIX, Friedrich Carl von Savigny, denominou-se "System des heutigen römischen Rechts [Sistema do direito romano atuall”, publicada em 1849. A referência para tradução da obra em português é a seguinte: (SAVIGNY 2004).

${ }^{6}$ A inspiração dessa crítica ao iluminismo político-jurídico adviria da compreensão histórica de autores como Edmund Burke e Herder (CASTANHEIRA NEVES, 2010, p. 205). Ainda assim, Franz Wieacker destaca a herança jusracionalista na Escola História: "A Escola Histórica do direito tem-se a si própria ao mesmo tempo como vencedora do direito natural e sua herdeira” (WIEACKER, 1967, p. 425). 
considerável da vida privada ${ }^{7}$, serviu como freio a tais discussões de teoria do direito, talvez apenas arranhada pela Lei da Boa Razão. Esse arranhão, no entanto, não significou aqui a reordenação do direito civil nos moldes que foram vistos na Europa no século XIX, que, já nos primeiros anos, experimentara a definitiva transição para a modernidade jurídica, em particular por meio do Código Civil francês.

A simbólica codificação civil francesa resultou, por sua vez, do estabelecimento de uma cultura jurídica diametralmente oposta à germânica. Para a Escola da Exegese, o direito positivo identificava-se de forma estática com a lei escrita e com a vontade geral plasmada no Code Civil, de modo a relegar o jurista e doutrinador ao papel de seu interpretador submisso ${ }^{8}$. O código pretendia ser fonte unitária, completa e acabada do direito, dispensando qualquer outra normatividade. No sentido contrário, a Escola Histórica Alemã propôs a construção do positivo como expressão imediata da realidade histórico-social, de forma orgânica e naturalmente evolutiva. Dessa forma, a história jurídica desempenhava o papel dogmático fundamental de revelar o direito tradicional (HESPANHA, 2017, p. 439).

Para Friedrich Carl von Savigny (1779-1861), principal expoente da escola, o fator embrionário do direito seria sempre o espírito do povo, o Volksgeist (HESPANHA, 2017, p. 440), "compreendido na unidade evolutiva do seu todo histórico-cultural" (CASTANHEIRA NEVES, 2010, p. 204). Partindo dessa centralidade do povo e da cultura na formação do direito, surge a conclusão defendida pela Escola Histórica de que o Código Civil Napoleônico, pensado para outro povo e outra história, não poderia ser recebido nos territórios germânicos. Assim, ao contrário de países como Portugal, Itália e Espanha, que adotaram de forma mais ou menos coesa o Código Napoleônico

\footnotetext{
${ }^{7}$ Ainda no século XIX, as ordenações possuíam vigência no Brasil em conjunto com "normas de direito canônico, do direito romano (subsidiariamente nas decisões judiciais), a jurisprudência metropolitana e colonial, e os costumes" (WEHLING; WEHLING, 1994, p. 303). Arno e Maria José Wehling também destacam a predominância do direito canônico em assuntos de família (1994, p. 293), assim como Airton Seelaender afirma que a temática da casa era também objeto do direito canônico (SEELAENDER, 2017, p. 347). A Lei da Boa Razão, informada por paradigmas jusracionalistas, pretendeu nivelar as camadas de normatividade e sujeitá-las ao crivo da racionalidade, procurando limitar a valência do direito canônico nos tribunais temporais (HESPANHA, 2017, p. 359). Por outro lado, Hespanha defende que "[é] provável que a sua excussão [da Lei da Boa Razão] se tenha confrontado com muitas resistências e tenha sido menos efetiva do que prometia" (HESPANHA, 2017, p. 360).

${ }^{8}$ Tal parece se justificar pelo contexto revolucionário da França do final do século XVIII e início do século XIX, em que as vias jurisprudenciais ou doutrinárias não eram capazes de responder de forma suficiente, em termos jurídicos, à necessidade de ruptura com as estruturas do Antigo Regime. Essa redução no panorama interpretativo colocada em movimento pelo processo de "panlegiferação" e codificação resultou no que Paolo Grossi cunhou de "absolutismo jurídico" (GROSSI, 1988). Mesmo assim, sabe-se que o saber jurídico produzido nesse período não se limitou, na prática, a uma "seca descrição de leis" e herdou categorias fundadas no direito natural como descrito pelo jusracionalismo. Nesse sentido, cf. (HESPANHA, 2017, p. $402-408$ e CASTANHEIRA NEVES, 2010, p. 182 ss.).
} 
(FACCHINI NETO, 2013, p. 76-79), a Alemanha apenas viu surgir um Código Civil em 1900, ausente a influência direta do direito francês.

Essa crítica não é de pouca importância. Em que pese hoje parecer fadado ao fracasso o desiderato do Código Napoleônico de esgotar todas as hipóteses de conflitos jurídicos, o que explicava a condição estática acima mencionada, tal tentativa organizacional do direito pretendia negar espaço ao arbítrio anterior à Revolução Francesa, tendo moldado inúmeras concepções que temos até a atualidade sobre o direito. O Code Civil foi responsável por estabelecer uniformidade de tratamento aos cidadãos franceses, sob o conceito de subjetividade jurídica, e tratou de premissas básicas de relações patrimoniais que ainda repetimos nas salas de aula das academias jurídicas. Em termos políticos, ademais, estabeleceu a garantia de que os direitos nacionais seriam colocados em prática e de que os objetivos revolucionários seriam atingidos por meio de uma legislação que se pretendia simples, precisa e uniforme (CARONI, 2013, p. 81).

A crítica de Savigny, portanto, opunha-se à própria ideia de que era possível construir um universo completo e diferente do anterior a partir das leis e fazia frente ao código que ficaria para posteridade como monumento da modernidade jurídica. A experiência de ingresso na modernidade jurídica pelos dois países europeus não poderia ser mais diferente. Boa parte das premissas levantadas pela Escola Histórica fizeram frente às propostas exegéticas francesas, recusando o culto à codificação emanada de uma autoridade, cujo próprio fundamento encontrava-se enfraquecido por uma banalização e efemeridade dos diplomas legais (HESPANHA, 2017, p. 408-409) ${ }^{9}$. Savigny protagonizou, naquela altura, um dos maiores debates acerca da possibilidade de codificação do direito alemão, que resultou na emblemática obra "Da Vocação de Nosso Tempo para a Legislação e a Ciência do Direito” (1814), na qual sustenta que a figura do código impediria a evolução e o natural desenvolvimento da história de um povo.

Dessa forma, a identidade jurídica e política de um povo não poderia depender da manifestação de um direito estatal, valorizando-se, ao contrário, os particularismos das "formas tradicionais e espontâneas de organização política" (HESPANHA, 2017, p. 409), na medida em que "o sentido cívico e a renovação cultural se juntaram na ofensiva contra a legislação mecanicista do Estado autoritário" (WIEACKER, 1967, p. 398). Assim, "[o] direito estaria antes inevitável e predominantemente preso, de acordo com uma necessidade forçosa, aos seus pressupostos históricos" (WIEACKER, 1967, p. 444).

\footnotetext{
${ }^{9}$ Lembre-se de que a Alemanha não conheceu um Estado nacional até a segunda metade do século XIX, de modo que o contexto no qual os debates acerca da codificação se desenvolveram é marcado por forte nacionalismo e uma concepção hegeliana sobre o Volksgeist (CAENEGEM, 1995, p. 183).
} 
A pretensão universalista do positivismo exegético, portanto, levaria à formação de um direito artificial e idealizado, pouco conectado com a sociedade destinatária e inaceitável para uma cultura de cariz romântico-nacionalista como a germânica. $\mathrm{O}$ direito também não poderia ser simplesmente deduzido da realidade por categorias axiomáticas-racionais, como defendia o jusracionalismo iluminista, uma vez que, em termos práticos, tal linha atribuía ao legislador a expressão legislativa da razão jurídica (CASTANHEIRA NEVES, 2010, p. 206).

Nesse contexto, a proposição central da Escola Histórica Alemã centrou-se na afirmação na natureza histórica e localizada da realidade humana e suas manifestações culturais, dentre as quais se encontrava a experiência jurídica (CASTANHEIRA NEVES, 2010, p. 204), bem como na irracionalidade das forças históricas. O direito constituiria manifestação histórica (assim como a língua, os costumes, a literatura etc.), e não volitivo-racionalista de um árbitro legislativo. Dessa forma, o "objecto da ciência jurídica é pré-determinado pela historicidade do direito do presente (e não pelas abstracções do jusracionalismo ou pelos comandos dos legisladores iluministas)" (WIEACKER, 1967, p. 403). Assim como a língua de um povo, que está em constante desenvolvimento, não poderia o direito ser codificado a partir um determinado estágio isolado da sociedade (CAENEGEM, 1995, p. 144).

Nesta linha, Savigny defendeu que a tarefa dos juristas consistiria em construir ou organizar o direito estabelecido, sem atividade inovadora significativa: o direito deveria ser encontrado e não feito (CAENEGEM, 1995, p. 209), do que ilustra muito bem a oposição inicial desta escola ao projeto de codificação do direito germânico (BOBBIO, 1995, p. 52). Portanto, embora o direito pertença em si à consciência do povo, é a ciência dos juristas sua portadora autêntica, bem como a responsável pelo processo intelectual de busca das fontes não estatais do direito. Ademais, segundo tal tradição, caberia aos juristas a aplicação concreta do direito a partir da rigorosa elaboração dos preceitos e conceitos jurídicos (CASTANHEIRA NEVES, 2010, p. 210). A compreensão da conexão interna e das relações entre conceitos e regras jurídicas constituiria, para Savigny, o cerne da cientificidade do trabalho do jurista e seria capaz de resultar na construção de completude do sistema (RUCKERT, 2016, p. 14).

Essa pretensão sistematizadora e dogmática legada da Escola Histórica é que está, justamente, na origem da Jurisprudência dos Conceitos (Begriffsjurisprudenz) ${ }^{10}$, também conhecida como pandectística, caracterizada como segunda fase da Escola Histórica Alemã. Ao confiar a apreensão das categorias jurídicas às regras abstratas, Savigny e a Escola Histórica Alemã abrem caminho para lógica formal conceitual (RUCKERT, 2016, p. 14), na medida em que se considera que "se o direito positivo pode ser

${ }^{10}$ Esta denominação foi atribuída apenas mais tarde por um de seus maiores críticos e representante principal da Jurisprudência dos Interesses, Philipp Heck (LARENZ, 1991, p. 63). 
construído sob a forma de um sistema dominado por grandes princípios, estes podem servir, como em todas as ciências, para deduzir daí conclusões particulares" (HESPANHA, 2017, p. 445). Dessa forma, o enfrentamento da questão do método resultaria na tentativa de fundamentar cientificamente as elaborações dogmáticas de direito privado (WIEACKER, 1967, p. 455).

Em suma, deparou-se com a necessidade de formalizar a cultura percebida de modo a operacionalizá-la para resolução de conflitos concretos. Desse modo, ao procurar romper com o jusnaturalismo por meio de uma formalização baseada no método científico, a Jurisprudência dos Conceitos abriu caminho ao desenvolvimento do que hoje denominamos positivismo jurídico, levando a apreensão do denominado "espírito do povo" ao monopólio dos juristas (WIEACKER, 1967, p. 455).

A construção formal e logicista dos conceitos foi marcada pela influência, no plano axiológico, da lógica individualista e contratualista do liberalismo burguês, e, no plano epistemológico, pela perspectiva jusracionalista kantiana (WIEACKER, 1967, p. 452), elaborando-se formulações conceituais que servissem como verdadeiros imperativos categóricos. Lembre-se que, para Kant, a compreensão do mundo (e a abordagem da natureza que podia ser extrapolada para o direito) passava pela elaboração de máximas universais: o modelo de ciência era um "discurso de categorias teoréticas" (WIEACKER, 1967, p. 400). A cientifização do direito, assim como sua desejada simplificação, passaria necessariamente pela ordenação principiológica (RUCKERT, 2016, p. 15).

A transposição desta lógica para o campo jurídico resultou na tentativa de redução do direito a categorias racionais por meio da formulação de conceitos firmes e universalizantes, derivados da interpretação autêntica da consciência popular. Assim, "positivos eram os conceitos jurídicos, genéricos e abstratos, rigorosamente construídos e concatenados, válidos independentemente da variabilidade da legislação positiva" (HESPANHA, 2017, p. 399).

A teoria do conhecimento jurídico proposta pela pandectística, assim, baseava-se no formalismo dos conceitos, obtidos também por meio das fontes de direito romano (GROSSI, 2000, p. 8), das quais se extrai a herança do movimento do usus modernus pandectarum. Seu principal expoente, Georg Friedrich Puchta (1798-1846) preocupou-se especificamente com a "elaboração de um sistema lógico-categorial a partir do 'direito comum”" (CASTANHEIRA NEVES, 2010, p. 212).

Para Puchta, a construção desta lógica formal se assemelharia a uma pirâmide: quanto maior a altura, menor a abundância de matéria, assim como maior a perspectiva de aplicação do conceito abstrato (sendo a recíproca verdadeira). No vértice da pirâmide, encontra-se o conceito mais geral e abstrato possível, retirado da própria filosofia do direito (LARENZ, 1991, p. 22, 26). Assim, a interpretação do direito obedeceria à subsunção de conceitos inferiores a conceitos superiores, de forma hierarquicamente 
organizada, de tal modo que "mesmo a mais concreta das normas jurídicas do sistema podia ser deduzida do cume do sistema axiomático exclusivamente por meio de conceitos definitórios" (WIEACKER, 1967, p. 454).

Ao sistematizar esta genealogia dos conceitos, Puchta afirma que a missão da ciência reside em:

reconhecer as proposições jurídicas no seu nexo sistemático, como sendo entre si condicionantes e derivantes, a fim de poder seguir-se a sua genealogia desde cada uma delas até ao princípio comum e, do mesmo modo, descer do princípio até ao mais baixo dos escalões (PUCHTA, 1847, p. 34 apud LARENZ, 1991, p. 24).

Um sistema de tal modo delineado abarcaria a totalidade das proposições jurídicas, permitindo o conhecimento, até mesmo, daquelas mais ocultas. Nessa construção linear e contínua, não haveria espaço para lacunas, uma vez que a estrita observação do rigor lógico seria capaz de deduzir das normas jurídicas isoladas a resposta para todas as situações concretas (WIEACKER, 1967, p. 457). A linearidade lógica também resultaria necessariamente na justeza material da subsunção aos conceitos, pois os princípios por ela autonomizados, tal como uma fórmula matemática, resultariam na decisão correta (WIEACKER, 1967, p. 495).

É nessa linha que Franz Wieacker sustenta que o desenvolvimento da Jurisprudência dos Conceitos em Puchta teria resultado, mais tarde, num paradoxo com relação à herança da Escola Histórica Alemã. Isso porque a construção dos conceitos com fundamento na epistemologia kantiana, cuja pretensão demonstrou-se, ao cabo, racional, abstrata e universalizante, retoma um racionalismo sistemático normativo cuja crítica esteva na origem da Escola Histórica: "O formalismo sistemático e conceitual do jusracionalismo foi, portanto, ainda largamente utilizado por Puchta e pela ‘jurisprudência construtiva’ do jovem Ihering” (WIEACKER, 1967, p. 427).

A história e o sistema seriam irreconciliáveis numa dimensão pragmática, tendose optado, ao final, pela exigência científica de sistematização e formalismo, recorrendose, para tanto, ao estudo das Pandectas (CAENEGEM, 1995, p. 146). Em razão disso é que seria possível afirmar que "o legado científico-jurídico da escola histórica se traduziu numa hermenêutica que culminou numa dogmática” (CAENEGEM, 1995, p. 213). O historicismo e o racionalismo que constituíram os componentes dominantes do pensamento jurídico alemão oitocentista teriam se rendido, ao final, à exigência de ordem prática de segurança jurídica (LARENZ, 1991, p. 39). Talvez o maior simbolismo desta constatação resida no fato de que o grande produto cultural da Escola Histórica Alemã veio a ser, justamente, a codificação civil alemã de 1900: o BGB (Bürgerliches 
Gesetzbuch) teria tentado garantir igualdade jurídica e justiça por meio de uma legislação principiológica inspirada no conceitualismo da pandectística ${ }^{11}$.

No plano teórico, entretanto, o dogmatismo puro e o ideal de construção formal dos conceitos não passaram imunes às críticas. A partir do final do século XIX, começam a surgir elaborações teóricas voltadas à prática normativa, rejeitando a premissa teórica de dedução da norma a partir do conceito (WIEACKER, 1967, p. 457). Nesta linha, menciona-se o desenvolvimento, em oposição à Jurisprudência dos Conceitos, da Jurisprudência dos Interesses, especialmente na figura de Philipp Heck e de Ihering, em sua segunda fase de produção (na qual teria cunhado, de forma pejorativa, o termo "jurisprudência dos conceitos"), como movimento teórico voltado à realidade jurídica com clara influência do utilitarismo anglo-saxão de Jeremy Bentham (BRONZE, 2003, p. 154).

A relativamente longa digressão teórica realizada neste tópico não serve a fins supérfluos. Num estudo histórico-comparado como o proposto, esta exposição se destina a estabelecer a premissa de comparação, a estrutura que permite enxergar o campo jurídico brasileiro do séc. XIX por meio da lente do conceito de tradução cultural, entendido como chave de compreensão dos movimentos migratórios entre diferentes culturas.

Assim, entende-se que a importação de uma teoria jurídica de um país por outro resultará sempre num processo matizado: o conceito ou instituto jurídico circulante não será meramente recebido ou rejeitado, mas passará por uma tradução a partir das lentes interpretativas do campo jurídico receptivo. É apenas a partir do conhecimento da premissa de comparação, no entanto, que se torna possível considerar os diferentes significados e significantes presentes em cada contexto, iluminando aspectos estruturantes do pensamento legal com a premissa de que contatos interculturais não se dão entre entidades fechadas e opostas (FOLJANTY, 2015, p. 6-9).

Um olhar atento a tais nuances pode evidenciar os danos e acréscimos decorrentes da fragmentação das "produções culturais do sistema de referências teóricas em relação às quais as ideias se definiram" (BOURDIEU, 2016, p. 3). Foi com este olhar atento às assimetrias entre os contextos europeu e latino-americano que procuramos ler os intercâmbios culturais entre Brasil e Alemanha no século XIX, retratados na obra de Teixeira de Freitas.

\footnotetext{
${ }^{11}$ Joachim Rückert afirma que o ideal traçado pelo BGB de fato não foi atingido, mas isso não poderia ser atribuído a um atraso ou ilusão de seus idealizadores. O Código não teria tido chance, pois chegou cedo demais, apenas atingindo condições de efetividade a partir da estruturação do direito público e constitucional em consonância, o que apenas teria ocorrido após a metade do século XX (RÜCKERT, 2016, p. 27 e ss.).
} 


\section{CULTURA JURÍDICA BRASILEIRA DO SÉCULO XIX - AUGUSTO TEIXEIRA DE FREITAS}

Os processos colonizadores da América e a assídua frequência da elite brasileira em universidade europeias, especialmente em Coimbra, garantiram uma ampla circulação das ideias jurídicas modernizantes do velho ao novo continente. Assim, embora não se possa afirmar a manifestação expressa e direta da influência da cultura jurídica alemã no Brasil, é possível identificar alguns traços de parentesco e coincidência entre as literaturas jurídicas produzidas lá e cá, traduzidas pelo filtro da cultura jurídica portuguesa e pela constante transação entre elites da antiga metrópole e colônia (HESPANHA, 2017, p. 428-435) ${ }^{12}$.

É evidente, no entanto, que a perspectiva histórico-comparada proposta tem de levar em conta que, ao passo que, na Europa ocidental, desenvolviam-se as estruturas modernas da teoria do direito, em solo brasileiro as novidades teóricas tinham de se adaptar ao conturbado contexto político de nascimento de um império independente, no qual a questão central residia na construção de uma ordem jurídica estável e correspondente à identidade nacional que se pretendia construir.

Nesse intercâmbio entre velho mundo e novo continente, o iluminismo jurídico característico da modernidade seria responsável por garantir que a eficiência técnica e a pretensa completude dos ordenamentos europeus justificassem e explicassem sua transposição a outras dimensões locais, num "proceso, dulcemente forzado, de civilización" (PETIT, 2011, p. 22). Basta atentar ao fato de que a Lei da Boa Razão, que orientava a leitura das Ordenações Filipinas, estabelecia como parâmetro para preenchimento das lacunas legais a utilização da recta ratio do direito estrangeiro, justificando o uso de soluções presentes nos códigos europeus na ausência de disposição específica (BARBOSA, 2008, p. 362).

Assim, a ordenação do direito civil, que teria enfrentado resistência muito maior do que em campos de direito público em razão de sua ligação às realidades sociais (BRAGA DA CRUZ, 1981, p. 26-27), serviu como parâmetro da própria modernização dos aspirantes estados modernos, na medida em que

la existencia de un ordenamiento dotado de garantías eficaces en la protección de personas y de bienes ("a certain security of the person and property", según la expresión, antes recogida, del moralista escocés) constituía la prueba para apreciar la 'civilización' de una dada sociedad política y aceptar entonces su

\footnotetext{
${ }^{12}$ António Manuel Hespanha menciona também a influência da pandectística em autores portugueses a partir de meados do século XIX, como Coelho da Rocha e Guilherme Moreira, nos quais já se manifestam os ideais de sociedade orgânica e necessidade de sistematização do direito de modo conceitual (HESPANHA, 2017, p. 433).
} 
inclusión en el selecto club que formaban las potencias occidentales (PETIT, 2011, p. 27).

Para além disso, em terras tupiniquins, a criação das faculdades de direito do império, em 1827 (CARVALHO, 2008, p. 69), garantiu as bases para proliferação de uma cultura jurídica local e construção de um caminho de desenvolvimento legal próprio, ainda que muito ligado a tais quadros europeus (FONSECA, 2006b, p. 346). Da segunda metade do século XIX em diante, os primeiros traços de particularidade do direito brasileiro em face da metrópole começam a se manifestar, notadamente em razão da formação nacional dos lentes das faculdades de direito ${ }^{13}$ e do gradual afastamento quanto à realidade portuguesa (FONSECA, 2006b, p. 345-347). A tendência à juridicização das relações privadas, ademais, potencializou aos poucos o papel dos juristas letrados nas relações privadas e colaborou para a ascensão da figura do bacharel (SEELAENDER, 2017, p. 367).

A partir daí, pode-se falar na efetiva existência de uma cultura jurídica com contornos legitimamente nacionais, ou seja, estabelece-se no Brasil um processo muito particular de produção e circulação de ideias jurídicas, estruturadas por meio de uma configuração discursiva própria e autores com circulação autônoma no campo jurídico. A independência da antiga metrópole é paulatinamente construída também no âmbito do direito.

É nesse contexto que Teixeira de Freitas (1816-1883) ${ }^{14}$ aparece como um dos personagens centrais no desenvolvimento da cultura jurídica brasileira da modernidade, especialmente se tivermos em mente a preponderância do papel da doutrina jurídica, bem como do corpo de juristas formado na primeira geração das faculdades de direito brasileiras, num período pré-codificação (BARBOSA, 2008, p. 370).

Formado em Pernambuco, cuja escola em oposição à de São Paulo teria mantido um tom mais académico e inspirado no romantismo alemão (FONSECA, 2006b, p. 346), Teixeira de Freitas pretendeu desenvolver um projeto de preservação e consolidação da tradição jurídica luso-brasileira (POUSADA, 2006, p. 16), num país que "procurava um sentido de independência e de genuinidade também no plano

\footnotetext{
${ }^{13}$ As primeiras instituições de ensino superior do Brasil datam apenas de 1827. Segundo José Murilo de Carvalho, "foi política sistemática do governo português nunca permitir a instalação de estabelecimentos de ensino superior nas colônias", ao contrário da América espanhola. Também segundo o autor, a formação de políticos em Coimbra desaparece após 1853 (CARVALHO, 2008, p. 69-80).

${ }^{14}$ Augusto Teixeira de Freitas nasceu em agosto de 1816 na vila de Cachoeira, hoje no estado da Bahia. Estudou direito na Academia de Olinda entre 1832 e 1837, com um período intercorrente em São Paulo entre 1833 e 1835. Em 1844, foi nomeado auxiliar do Conselho de Estado, no Rio de Janeiro, seguindo como jurista consultou do Império nas empreitadas seguintes. Foi presidente do Instituto dos Advogados Brasileiros (1857). Atuou como advogado até sua morte, em 1883 (MEIRA, 1983).
} 
jurídico" (HESPANHA, 2017, p. 435). Assim, revela-se como um de seus grandes atributos o desenvolvimento de projetos de características modernistas, sem desconhecer, entretanto, a larga tradição jurídica anterior, tanto portuguesa como brasileira, assim como os usos modernos do direito Romano (FLORES, 2006, p. 2).

É certo que tal hibridismo torna bastante árdua a tarefa de classificá-lo conforme um único seguimento teórico europeu do período, resultando numa conjugação entre elementos da Escola Histórica e do direito natural (FONSECA, 2006a, p. 71). Ricardo Marcelo Fonseca menciona que Teixeira de Freitas, apesar de ser apresentado, por vezes, como bastião do tipo ideal de jurista moderno, fundamentou suas conclusões:

[...] em juristas pertencentes ao período do 'ius commune', ou ao do humanismo jurídico quinhentista ou a de um jusnaturalismo racionalista (ou ainda com um misto de tudo isto) que estava muito à vontade (como peixe dentro d'água) com toda a reflexão jurídica do período pré-moderno (FONSECA, 2011, p. 351).

Isso pode revelar justamente a característica central da teoria jurídica no Brasil do século XIX: a "tensão entre arcaísmo e inovação; entre pré-modernidade e modernidade; entre a era do 'ius commune' e a era legislativa” (FONSECA, 2011, p. 344). Naquela altura, o horizonte de referência discursivo do jurista brasileiro colocavase no confronto entre as tradições locais e aquelas herdadas do direito comum e as tendências modernizantes vindas da Europa (FONSECA; SEELAENDER, 2008, p. 9. $10)$.

Nesse contexto, Teixeira de Freitas procurou na tradição letrada romano-lusitana a segurança contra o uso de soluções descoladas da realidade social, inspirando-se na praxística portuguesa dos séculos XVII e XVIII e no usus modernus pandectarum alemão (HESPANHA, 2017, p. 430). Além disso, as referências ao direito Romano são múltiplas, mesmo que mediadas por autores da tradição germânica, francesa ou lusitana. $\mathrm{Na}$ defesa da necessidade de formulação de um Código Geral que regrasse "os elementos de todos os direitos possíveis em todas as esferas da vida jurídica”, por exemplo, o jurista atribuiu inspiração aos últimos dois títulos do Digesto, como já teria sido compreendido por Pothier em suas Pandectas (TEIXEIRA DE FREITAS, 1867, p. 323).

Ainda que não se possa menosprezar a influência da multiplicidade de tradições acima referidas, no entanto, a leitura da produção intelectual de Teixeira de Freitas revela muito rapidamente a predominância do influxo germânico na concepção do jurisconsulto acerca das categorias gerais do direito e de questões metodológicas da sistematização normativa. O autor refere-se à Alemanha como "o paiz da meditação, 
onde a sciencia do Direito, associando-se á historia, e á philologia, tem alcançado os mais brilhantes triumphos" (TEIXEIRA DE FREITAS, 1857, p. 39) ${ }^{15}$.

Dessa forma, é possivel verificar com abundância em Freitas preocupações semelhantes àquelas desenvolvidas pela Escola Histórica e pela Jurisprudência dos Conceitos, como a de sistematização das normas e estabelecimento de uma estrutura conceitual abstrata, que possibilitasse a subsunção de categorias jurídicas.

A atenção dispendida por Teixeira de Freitas para com a sistematização normativa e sua postura rigorosa quanto à coerência interna de seus projetos podem ser notadas nos dilemas quanto à confecção do Código Civil, tarefa para a qual foi contratado em 1859. Em 1867, passada quase uma década do início da empreitada, Teixeira de Freitas encaminha uma carta para o então Ministro e Secretário de Estado e dos Negócios da Justiça do Governo Imperial, Martim Francisco Ribeiro de Andrada, manifestando sua incompatibilidade de ideias com as pretensões governistas acerca do Código e a impossibilidade de cumprir os termos do contrato. Isso porque, enquanto o governo pretendia que o Código Civil caminhasse ao lado do já existente Código Comercial (1850), Teixeira de Freitas não vislumbrava a possibilidade de tratar ambos os assuntos civis em diplomas separados, tendo de excluir matérias do Código Civil, pois pertenciam ao já existente Código de Commercio. Pretendia, assim, iniciar a redação de um novo código, abrangendo todas as questões de tal natureza:

O Governo espera por um Projecto de Cod. Civil no systema d'esse Esboço, systema traçado no meu contracto de 10 de Janeiro de 1859; e para mim já não ha possibilidade de observar tal systema, convencido, como estou de que a empreza quer diverso modo de execução. O Governo quer um projecto de Cod. Civil, para reger como subsidio ou complemento de um Cod. de Comm., intenta conservar o Cod. Commercial existente com a revisão que lhe destina; e hoje minhas idéas são outras, resistem invencivelmente á essa calamitosa duplicação de leis civis, não distinguem no todo das leis d'esta classe, algum ramo que exija um Cod. de Commercio. O Governo só pretende de mim a redacção de um projecto de Codigo Civil; e eu não posso dar esse Codigo ainda mesmo comprehendendo o que se chama direito commercial, sem começar por um outro Codigo, que domine a legislação inteira (TEIXEIRA DE FREITAS, 1867, p. 322).

Dessa forma, o Código Civil deveria abranger todas as questões civis, com ou sem a finalidade de lucro pecuniário, o que conferiria coerência e cientificidade ao ordenamento jurídico. O jurista preocupava-se em restabelecer a "unidade da legislação" e em "extremar os verdadeiros limites da codificação civil" (TEIXEIRA DE FREITAS, 1867, p. 323).

${ }^{15}$ Optamos por manter a grafia do original nas citações de textos da época. 
Foi assim que, em resposta às críticas da comissão encarregada de analisar o projeto de Código Civil, cuja preocupação residia na clareza e na inteligibilidade dos artigos por pessoas comuns (com citações, nesse sentido, a Jeremy Bentham), Teixeira de Freitas rebateu voltando sua atenção à importância da abstração das leis que possibilitasse maior abrangência e cientificidade, em linha com a percepção da tradição conceitualista germânica: "As leis civis são tanto mais perfeitas, quanto mais comprehensivas; são tanto mais comprehensivas, quanto mais abstractas" (TEIXEIRA DE FREITAS, 1865, p. 18).

A busca por um espírito do povo e unidade num país recém-independente guiou, então, tal pretensão de sistematização científica do direito, sendo possível encontrar na obra de Freitas homenagem e admiração por Savigny e seu fundamento na realidade das relações jurídicas. Na Introdução à Consolidação das Leis Civis, cita o autor no mínimo dezenove vezes, adjetivando-o como "profundo" e "sábio" (TEIXEIRA DE FREITAS, 1857 , p. 98, 105,112) e referindo-o por sua "assombrosa intelligencia" (TEIXEIRA DE FREITAS, 1859, p. 86). Além disso, afirmou ter se inspirado, na confecção da Consolidação, no método adotado pelo alemão quanto à divisão entre direitos reais e pessoais, utilizando-o como justificativa e referência de suas escolhas metodológicas no projeto: "O proprio Savigny, primeira autoridade n'estas materias, não deixa de justificar o methodo, que havemos adoptado" (TEIXEIRA DE FREITAS, 1857, p. 105).

$\mathrm{Na}$ "Nova apostila à censura do senhor Alberto de Moraes Carvalho sobre o Projecto do Codigo Civil Portuguez", de 1859, em que Teixeira de Freitas dialoga com o conhecimento jurídico produzido na antiga colônia, a ideia de estruturação da norma a partir do conceito savignyano de relação jurídica é central. $O$ autor critica a parca atenção dada por Antônio Luís Seabra, jurisconsulto português que elaborou o projeto de Código Civil Português, às questões metodológicas. Sobre a separação das matérias legislativas, por exemplo, discorda do projeto lusitano quanto à abrangência dos direitos da personalidade no Código Civil, visto que seu tratamento já havia se dado por ocasião da Carta Portugueza (TEIXEIRA DE FREITAS, 1859, p. 17-18). Encerra as anotações ao "Systema do Projecto" com uma citação do System de Savigny que apela justamente para o uso adequada do método (TEIXEIRA DE FREITAS, 1859, p. 88).

A obra de Teixeira de Freitas, assim, demonstra "uma preocupação conceitualista e abstrata tremendamente apurada, denotando um 'cientificismo jurídico' sem precedentes nos autores brasileiros” (FONSECA, 2006b, p. 354-355). Aderindo a noção de System de Savingy e Puchta, alia-se ao claro objetivo de estabelecer uma tradição jurídica que correspondesse ao espirito do povo brasileiro (FLORES, 2006, p. 13).

Destarte, o primeiro passo da empreitada sistematizadora de Teixeira de Freitas concretizou-se por meio da Consolidação das leis civis (1857), por meio da qual o autor teria pretendido sistematizar a complexidade e multiplicidade de formas normativas presentes no ordenamento jurídico daquela altura. Até então, convivia-se com um 
emaranhado de legislações brasileiras modernizantes e liberais (como a Lei de Terras e o Código Criminal do Império), portuguesas de caráter jusracionalista (como a Lei da Boa Razão) e ainda as Ordenações Filipinas de 1603, que ganham novos contornos com a independência em 1822 (FONSECA, 2006a, p. 64).

Para além da complexidade advinda da multiplicidade de fontes, a exegese da abundância de atos legislativos não sistematizados representava um desafio adicional, na medida em que o racionalismo introduzido pela interpretação conforme a recta ratio (Lei da Boa Razão) se chocava com a longa tradição jurisprudencial norteada pelo Digesto romano (BARBOSA, 2008, p. 362). Por fim, esse quadro era ainda marcado pela herança da tradição jurídica do Antigo Regime, no qual o direito comum (ius commune) compunha-se numa "geometria variável", composta por diversas ordens normativas sobrepostas e entrecruzadas que possibilitavam a existência de um direito próprio da outrora colônia (HESPANHA, 2006, p. 70).

A necessidade de sistematização mostrava-se autoevidente ${ }^{16}$ e motivou Teixeira de Freitas a "identificar aquilo que estivesse solidamente ancorado na prática jurídica brasileira" (HESPANHA, 2017, p. 433). O produto de tal empreitada, em razão da notável sistematicidade e organização, logrou imensa repercussão tanto no âmbito acadêmico quanto na prática forense do Brasil Imperial, constituindo guia e referência aos tribunais e aos juristas da nação, fazendo as vezes de direito vigente (REIS, 2015, p. 14). Gustavo Siqueira menciona, por exemplo, o uso da Consolidação em decisões do Supremo Tribunal Federal como fundamento para justificar a não aplicação das Ordenações, classificadas por Freitas em desuso quanto a certos tópicos (SIQUEIRA, 2017, p. 553-554). Dessa forma, a empreitada organizadora de Teixeira de Freitas teria marcado a descontinuidade das "renitentes permanências do direito comum na ordem jurídica privada” (FONSECA, 2006a, p. 69-76).

Já na Consolidação, portanto, Teixeira de Freitas teria atendido ao rigor sistemático proposto pelo conceitualismo alemão, estabelecendo a divisão da normativa civil entre Parte Geral e Especial (modelo posteriormente adotado pelo BGB alemão) e propondo a unificação do direito comercial ao civil, rejeitando, assim como a tradição historicista alemã, a ideia de completude do Code Civil Francês (HESPANHA, 2010, p. $149)^{17}$, em que pese a inegável influência do direito francês na cultura jurídica do

\footnotetext{
${ }^{16}$ Gustavo Siqueira sustenta que o argumento da insegurança jurídica dos quadros legislativos civis foi central na defesa da codificação de 1916. Nos anos precedentes ao primeiro código, o autor encontrou menção a decisões do Supremo Tribunal Federal utilizando-se das Ordenações Filipinas como fundamento e outras em que estas eram consideradas revogadas (SIQUEIRA, 2017, p. 553).

${ }^{17} \mathrm{O}$ afastamento da cultura jurídica brasileira da tradição francesa pode também explicar a ausência de uma vontade codificadora imediatista (FONSECA, 2006a, p. 71).
} 
Império $^{18}$.

É certo, no entanto, que o esforço de consolidação das normas civis não se resumiu, na prática, à mera compilação. Pelo contrário, resultou também numa ressignificação semântica das normas compiladas (FONSECA, 2011, p. 350), na medida em que "a interpretação opera a historicização da norma, adaptando as fontes a circunstâncias novas, descobrindo nelas possibilidades inéditas, deixando de lado o que está ultrapassa ou o que é caduco" (BOURDIEU, 2016, p. 233).

A Consolidação fundamentou, por exemplo, decisões judiciais que iam de encontro às disposições das Ordenações Filipinas, apesar do teor da Lei de 20 de outubro de 1823, que havia declarado "em vigor a legislação pela qual se regia o Brazil até 25 de Abril de 1821" na ausência de um novo código (SIQUEIRA, 2017, p. 550). Há menção expressa, inclusive, ao desuso de tal fonte normativa (TEIXEIRA DE FREITAS, 1857, p. 59, 181, 439, por exemplo). Teixeira de Freitas, ademais, classificou as Ordenações como "pobríssimas", necessitando de "copioso suplemento" (TEIXEIRA DE FREITAS, 1857, p. 25). Dessa forma, é razoável concluir que, ainda que os textos legais tenham se mantido relativamente inalterados, o quadro efetivo das fontes de direito alterou-se na recepção, na tradução e na incorporação das ideias jurídicas (HESPANHA, 2010, p. 150). Isso porque a sistematização operada implicou necessariamente mudanças estruturais e semânticas na configuração normativa. Sistematizar envolve necessariamente a escolha entre que normas são ou não elencadas, como são classificadas, em que ordem são apresentadas e assim por diante. Tudo isso aponta para o caráter inovador e central da Consolidação na cultura jurídica nacional da altura.

Segundo Ricardo Marcelo Fonseca, então, Teixeira de Freitas teria preenchido o perfil de jurista ligado ao cientismo e aos referenciais teóricos conceitualistas alemães, recebendo a herança da cultura jurídica europeia do período e absorvendo um paradigma moderno em contraposição à figura do jurista com referência a um jusnaturalismo escolástico. Essa busca pelo método científico e a recusa ao direito

\footnotetext{
${ }^{18}$ Alan Wruck Garcia Rangel demonstra, numa análise comparada, por exemplo, a presença de elementos do Código Civil Napoleônico no Esbôç̧o de Teixeira de Freitas (RANGEL, 2018, p. 183). As referências à cultura jurídica francesa, no entanto, não carregam a carga de admiração que Teixeira de Freitas demonstra pela tradição alemã. Há passagens, inclusive, de crítica expressa ao direito francês. A título de exemplo, transcrevo trecho em que o jurisconsulto se refere, em crítica ao projeto de Código Civil Português de Antônio Luís de Seabra, ao "veneno" introduzido pelo direito francês: "Todas estas transgressões da Carta, todas estas aberrações, são desastrosos effeitos de um veneno infiltrado pelo Direito Francez, com seus inúmeros expositores e commentadores. É raro que os Jurisconsultos, ainda mesmo tratando da theoria geral da Sciencia, não tinjão seus escriptos de uma côr local do Direito de seu Paiz! Imitou-se a degradação civica das Leis Francezas, o privilégio de certos direitos civis que o legislador á seu talante póde conceder ou negar, e que os estrangeiros - entes de outra especie - não tem a fortuna de gozar" (TEIXEIRA DE FREITAS, 1859, p. 176-177).
} 
meramente retórico, característicos do discurso jurídico do final do século XIX, estiveram na base da reforma ao ensino jurídico promovida no guião da proclamação da República do Brasil (Decreto 1030-A, de 1890, e Decreto 1232-H, de 1891), por meio da qual se suprimiu a obrigatoriedade do ensino eclesiástico e instituiu-se o ensino de história do direito no âmbito universitário (FONSECA, 2006b, p. 364).

Já a posição de Teixeira de Freitas a favor da codificação é controversa. Sabe-se que a Escola Histórica alemã cuidou da tarefa de denunciar os déficits do modelo codificatório francês, visto que esse reduziria a complexidade da realidade social a um sistema normativo que careceria, por questão de impossibilidade lógica, de completude. Aliando essa compreensão à enunciada inspiração do jurista brasileiro no pensamento jurídico alemão, seria justo esperar que fosse igualmente contrário a um projeto de codificação civil no Brasil.

No entanto, na linha da promessa de um novo código feita pela Constituição de 1824 e da reivindicação de uma codificação capaz de contribuir para a unidade nacional (REIS, 2015, p. 33), o jurisconsulto trabalhou num Esbôço de Código Civil composto por cerca de 4.900 artigos, louvado por sua consistência, mas não chegou a ser aprovado $^{19}$. Destacou-se pela inclusão no projeto de uma Parte Geral preocupada com conceitos como de pessoa, bens e fatos jurídicos, exatamente como se passou posteriormente com o BGB (COUTO E SILVA, 1988, p. 169). O jurista, inclusive, aludiu expressamente à influência alemã na configuração do Esbôço, fazendo menção ao exemplo tomado dos "escriptores da escola germânica" quanto ao estabelecimento de uma seção sobre os fatos (TEIXEIRA DE FREITAS, 1867, p. 322).

A robustez de um esboço com 4.900 artigos reflete, em parte, o ambiente teórico e cultural de formação do meticuloso jurista. Isso porque o advento do cientificismo jurídico e a influência do conceitualismo alemão, cujo modus operandi passava necessariamente pela apreensão e pela definição abstratas das categorias, resultava na tentativa de apreensão de todo o universo jurídico-civil no código, assegurando ao direito um tratamento propriamente científico. Teixeira de Freitas chegou a afirmar que "sem definir, sem distinguir, sem dividir, nunca me foi possivel formular a parte imperativa das matérias”, entendendo não haver doutrina apta para a tarefa:

Recommendam os mestres que a legislação não defina, porque as definições são da doutrina. Onde está, porém, a doutrina? Em parte nenhuma, porque nem os livros nem a escola ensinam nada mais do que uma historia de opiniões, ou questões de palavras, a ponto de não estar ainda liquida nem a noção significada pela palavra - direito (TEIXEIRA DE FREITAS, 1867, p. 322).

\footnotetext{
${ }^{19}$ Sobre o movimento de codificação tardio no Brasil e a vigência, significação e (des)continuidades das Ordenações Filipinas em território brasileiro até o início do século XX, cf. (FONSECA, 2006a).
} 
Dessa forma, advogou pela necessária "força obrigatoria para a significação das palavras do legislador, sobretudo das palavras technicas. Sem tal providencia não haverá lei boa, e reinará permanentemente incerteza na administração da justiça” (TEIXEIRA DE FREITAS, 1867, p. 324).

Assim como na tradição alemã, portanto, a conceituação dos termos jurídicos era tarefa prioritária e indispensável. Teixeira de Freitas chegou a sugerir a confecção de um Código Geral, separado do Código Civil, que tratasse daquela massa de matérias que, por terem relação com todos os ramos da legislação, não pertencem a nenhum em específico. Tal Código conteria "todas as definições necessarias, assim as das materias superiores como as das disposições de cada um dos codigos particulares de modo que n'estes ultimos nada se defina. Conciliamos d'est'arte o preceito com a necessidade" (TEIXEIRA DE FREITAS, 1867, p. 324).

Ainda com a Consolidação, o que Freitas tinha em mente era o feitio de um "extracto fiel" das Leis Civis, simplificando-as numa espécie de "codificação provisória”, contendo disposições em formato de artigos acompanhadas de citações das leis em vigor e de eventuais costumes estabelecidos contra ou além do texto (TEIXEIRA DE FREITAS, 1857, p. 23- 25). Tudo isso se justificava em razão da "imensa teia das leis extravagantes, que se têm acumulado no decurso de mais de dois séculos e meio" (TEIXEIRA DE FREITAS, 1857, p. 25) e da pobreza das Ordenações Filipinas (TEIXEIRA DE FREITAS, 1857, p. 25). Para Teixeira de Freitas, a situação de incerteza gerada pela insuficiência das Ordenações, pelo arbítrio permitido a título de boa razão e pela incompatibilidade de múltiplas disposições legais com a Carta Constitucional, exigia uma organização do estado legislativo. O jurista chegou a afirmar, na Introdução à Consolidação, que "As cousas tem chegado a tal ponto, que menos se conhece, e estuda, nosso Direito pelas leis, que o constituem; do que pelos Praxistas que as invadiram" (TEIXEIRA DE FREITAS, 1857, p. 25-26).

Os procedimentos sugeridos e adotados por Freitas podem muito bem exemplificar o rigor sistemático do conceitualismo alemão em busca dos conceitos superiores e abstratos que pudessem explicar as relações jurídicas:

Examinar as leis em seus próprios textos sem influencia de alheias opiniões, comparar attentamente as leis novas com as antigas, medir com precisão o alcance e as consequencias de umas e outras; eis o laborioso processo, que empregado temos para conhecer a substancia viva da Legislação.

Para achar, porém, os limites do Direito Civil; e a norma da exposição das matérias, que lhe pertencera; recorremos a estudos de outra natureza, consultámos os monumentos legislativos, revimos e meditámos as tradições da Sciencia; e com livre espirito procurámos essa unidade superior, que concentra verdades isoladas, penetra as mais recônditas relações, e dá esperanças de um trabalho consciencioso (TEIXEIRA DE FREITAS, 1857, p. 28). 
De tal forma, a assunção da posição a favor da codificação foi classificada como ambígua e traidora com relação à tradição da Escola Histórica Alemã ${ }^{20}$, na medida em que a um só tempo se inspirava no conceitualismo germânico e advogava a produção de um Código Civil.

Em contrapartida, é possível suscitar a hipótese de interpretar a posição modernizadora de Freitas de outra maneira: o desenvolvimento sistematizador da Escola Histórica na Jurisprudência dos Conceitos resultou na admissibilidade da ideia de um código, resultado da própria sistematização conceitual, de modo que a ambiguidade de Freitas pode resultar desse mesmo desenrolar da tradição alemã, que admitiu a codificação para construção daquele sistema. Dessa forma, assim como o BGB alemão resultou, de certo modo, do intento de abstrativização da pirâmide conceitualista, o Esbôço de Freitas seria a consequência da absorção de tal preocupação com a subsunção das normas a conceitos mais gerais.

O paradoxo de Freitas poderia ser atribuído, ainda, à constatação de que o Beruf de Savigny, que abrigou a discussão com Thibaut quanto à codificação do direito civil alemão, não circulou entre os juristas brasileiros do Império (REIS, 2015, p. 16), sendo que a maioria das referências de Freitas a Savigny residem no System e no Besitz. De tal modo, a absorção da tradição alemã não teria se dado quanto aos termos mais práticos e imediatos daquela experiência, mas sim quanto à abstrativização teórica que lhe era característica. Aqui, o conceito de tradução cultural pode ajudar a demonstrar que o processo de recepção de um conceito exógeno envolve sempre sua ressignificação, de maneira que a transposição conceitual não resulta apenas na aceitação ou rejeição da ideia, mas na construção de um novo caminho discursivo e semântico autônomo e diverso do original.

A explicação da aparente contradição, no entanto, não deve ser buscada de forma monocausal, mas tem de considerar o conjunto de tais hipóteses, bem como o fato de que as soluções jurídicas propostas por nossos juristas respondiam às contingencialidades de um país em construção, cujas instituições e pensadores voltavamse aos países "civilizados" em busca de modernização. Nesse sentido, "era preciso que os homens livres do Império tanto se reconhecessem quanto se fizessem reconhecer como membros de uma comunidade - o 'mundo civilizado', o qual era animado, então, pelo ideal de progresso" (MATTOS, 2017, p. 23). A linha que guia o processo de construção da cultura jurídica brasileira não é apenas de uma fidelidade à determinada escola de pensamento jurídico ou autor renomado, mas a de apropriação dos esquemas teóricos

\footnotetext{
20“Assim, se por um lado, ele parece adotar posição de resistência à exportação do Código Napoleão enquanto modelo de legislação perfeito e acabado, por outro lado, ao assumir o projeto de modernização do direito privado brasileiro pela codificação, Teixeira de Freitas trai a própria razão de ser da escola alemã" (RANGEL, 2018, p. 170).
} 
estrangeiros, advindos das nações civilizadas, conforme servissem ao projeto de modernização jurídica e alçassem o nascente Império brasileiro à categoria de civilização.

De todo modo, o Código que surge apenas em 1916 pode ser considerado, em certa medida, resultado do formalismo da pandectística e da busca, iniciada justamente por Teixeira de Freitas, por uma sistematização que correspondesse às necessidades pátrias. Embora malsucedida a formulação do Código Civil, portanto, a empreitada de Teixeira de Freitas teve "reflexos profundos no campo legislativo nacional" (REIS, 2015, p. 66). Ademais, apesar de não ter atingido vigência no Brasil, o projeto serviu como modelo ao processo codificatório latino-americano, tendo inspirado a consolidação do Código Civil Argentino por Dalmácio Vélez Sársfield, bem como outras codificações oitocentistas na América Latina (REIS, 2015, p. 69), revelando a importância do jurisconsulto do império na formação da cultura jurídica latino-americana daquela altura.

\section{CONSIDERAÇÕES FINAIS}

Este trabalho pretendeu demonstrar, ainda que de forma breve e introdutória, os processos e caminhos de circulação e absorção de ideias entre a tradição romanista germânica e a cultura jurídica brasileira em formação no século XIX, a partir da recepção, em Teixeira de Freitas, de estruturas teórico-metodológicas introduzidas pela Escola Histórica Alemã e pela Jurisprudência dos Conceitos. Partiu-se da compreensão de que o estudo histórico do pensamento jurídico constitui parte essencial da teoria do direito, apontando-se as raízes temporais e locais do que hoje temos como o único formato possível de sistematização legal.

As correntes germânicas apresentadas representaram a proposta de modernização do direito pelo espírito e pela tradição do povo, opondo-se ao modelo revolucionário e legiferante francês. Constituíram, assim, a base para o desenvolvimento do positivismo moderno por meio da atividade sistematizadora dos conceitos, propondo a reflexão quanto à historicidade das experiências jurídicas, afastando-as da ideia de moralidade.

Em termos de transposição dessas ideias para cultura jurídica brasileira, a posição de Teixeira de Freitas revela-se complexa e caracterizada por um ecletismo difícil de classificar, assim como se passa com boa parte dos juristas do Império. Ainda assim, é inegável a influência exercida em sua obra e trajetória pela Escola Histórica Alemã, bem como pelo posterior conceitualismo, empregado na conjugação das diversas fontes em favor da modernização do direito brasileiro. Pensando-se a partir da proposta de tradução cultural, as nuances da leitura efetuada por Teixeira de Freitas se destacam e confirmam a tese segundo a qual o processo de recepção e circulação de uma teoria pertencente à outra cultura, uma vez iniciado, segue seu próprio curso e conforma suas próprias regras. 
Dessa forma, é possivel concluir, pois, que Teixeira de Freitas representou a tradução, em todas as suas nuances ressignificatórias, da sistematicidade e do conceitualismo alemão para a realidade brasileira, constituindo exemplo da pandectística nacional na transição do jovem Império brasileiro ao modelo liberal de Estado nacional.

Tais constatações de caráter histórico podem contribuir à reflexão jurídica da atualidade na medida em que apontam para o caráter cultural da codificação, que, embora hoje nos pareça indispensável, é fruto de um contexto histórico bastante específico. Abre-se espaço, portanto, para pensar possibilidades que, assim como levado a feito pela Escola Histórica, apontem para a centralidade de fatores além do absolutismo legal, encontrados na complexidade das relações sociais de determinado povo. A partir dessa proposta, é possivel debater o papel do jurista, dos princípios e dos costumes na formação da juridicidade, assim como formatos mais plurais de experiência jurídica, o que se mostra essencial quando nos deparamos com a crise de legitimidade da democracia representativa na atualidade.

A reflexão sobre o pensamento de Teixeira de Freitas e sobre as disputas entre exegetas e historicistas, assim, ilumina a atualíssima disputa entre legisladores e juristas, na medida em que estudá-los consiste em melhor compreender a concorrência pelo monopólio da narrativa do dizer o direito. Talvez seja este, justamente, o papel do historiador do direito: o de questionar de forma crítica os pressupostos inconscientes das disciplinas dogmáticas, revelando a historicidade por detrás das soluções propostas.

\section{REFERÊNCIAS}

BARBOSA, Samuel Rodrigues. Complexidade e meios textuais de difusão e seleção do direito civil brasileiro pré-codificação. In: FONSECA, Ricardo Marcelo; SEELAENDER, Airton Cerqueira Leite (org.). História do Direito em Perspectiva: do Antigo Regime à Modernidade. Curitiba: Juruá, 2008.

BRAGA DA CRUZ, Guilherme. Obras esparsas: estudos de história do direito moderno. Coimbra: Coimbra Editora, 1981.v. 2.

BOBBIO, Norberto. O Positivismo Jurídico: Lições de Filosofia do Direito. Tradução Márcio Pugliesi et al. São Paulo: Ícone, 1995.

BOURDIEU, Pierre. O poder simbólico. Tradução Fernando Tomaz. Lisboa: Edições 70, 2016.

BRONZE, Fernando José. Alguns Marcos do Século na História do Pensamento Metodológico-Jurídico. Boletim da Faculdade de Direito, Universidade de Coimbra, Coimbra, 2003.

CAENEGEM, Raoul Charles van. Uma introdução histórica ao direito privado. São 
Paulo: Martins Fontes, 1995.

CAPPELLINI, Paolo. Systema Iuris. Milano: Giuffrè, 1984. v. 1.

CARONI, Pio. Lecciones de Historia de la Codificación. Madrid: Universidad Carlos III de Madrid, 2013.

CARVALHO, José Murilo de. A construção da ordem. Teatro das Sombras. 4. ed. Rio de Janeiro: Civilização brasileira, 2008.

CASTANHEIRA NEVES, A. Digesta. Coimbra: Coimbra Editora, 2010. v. 2.

CHALHUB, Melhim Namem. Direitos Reais. 2. ed. São Paulo: Revista dos Tribunais, 2013.

COUTO E SILVA, Clóvis V. do. O direito civil brasileiro em perspectiva histórica e visão de futuro. Revista de Informação Legislativa, Brasília, v. 25, n. 97, jan./mar. 1988.

DWORKIN, Ronald. Levando os direitos a sério. Tradução Nelson Boeira. São Paulo: Martins Fontes, 2010.

FACCHINI NETO, Eugênio. Code civil francês: Gênese e difusão de um modelo. Revista de Informação Legislativa, Brasília, v. 50, n. 198, p. 59-88, abr./jun. 2013.

FOLJANTY, Lena. Legal Transfers as a Processes of Cultural Translation: On the Consequences of a Metaphor. Max Planck Institute for European Legal History Research Paper Series, n. 9, 2015.

FLORES, Alfredo. O papel de Teixeira de Freitas no contexto do pensamento jurídico do séc. XIX. The Latin American and Caribbean Journal of Legal Studies, v. 1, n. 1, Berkeley Electronic Press, 2006.

FONSECA, Ricardo Marcelo. A formação da cultura jurídica nacional e os cursos jurídicos no Brasil: uma análise preliminar (1854-1879). Cuadernos del Instituto Antonio de Nebrija, Universidade Carlos III de Madrid: Editorial Dykinson, p. 97-116, 2005.

FONSECA, Ricardo Marcelo. A cultura jurídica brasileira e a questão da codificação civil no século XIX. Revista da Faculdade de Direito da Universidade Federal do Paraná, v. 44, 2006a.

FONSECA, Ricardo Marcelo. Os juristas e a cultura jurídica brasileira na segunda metade do século XIX. Quaderni Fiorentini per la storia del pensiero giuridico moderno, Milano, Giuffrè, v. 35, n. 1, p. 339-371, 2006 b.

FONSECA, Ricardo Marcelo; SEELAENDER, Airton Cerqueira Leite. Prefácio. In: FONSECA, Ricardo Marcelo; SEELAENDER, Airton Cerqueira Leite (org.). História 
do direito em perspectiva: do antigo regime à modernidade. Curitiba: Juruá, 2008.

FONSECA, Ricardo Marcelo. Teixeira de Freitas: um jurisconsulto "traidor" na modernização jurídica brasileira. Revista do IHGB, Rio de Janeiro, a. 172, n. 452, p. 341-354, jul./set. 2011.

GROSSI, Paolo. Assolutismo giuridico e diritto privato. Milano: Giuffrè, 1988.

GROSSI, Paolo. Scienza Giuridica Italiana: Un profilo storico (1860-1950). Milano: Giuffrè, 2000.

GROSSI, Paolo. O ponto e a linha. História do Direito e Direito Positivo na Formação do Jurista do Nosso Tempo. Revista Sequência, Florianópolis, n. 51, p. 31-45, 2005a.

GROSSI, Paolo. Absolutismo Jurídico. Da riqueza e da liberdade do historiador do direito. Revista Direito GV, São Paulo, v. 1, n. 2, p. 191-200, jun./dez. 2005 b.

GROSSI, Paolo. Mitologias jurídicas da modernidade. Tradução Arno Dal Ri Junior. Florianópolis: Boiteux, 2007.

GROSSI, Paolo. Oltre la Legalità. Bari: Editori Laterza, 2020.

GOMES, Orlando. Direitos Reais. 21. ed. Rio de Janeiro: Forense, 2012.

HESPANHA, António Manuel. Porque é que existe e em que consiste um direito colonial brasileiro. Quaderni Fiorentini per la storia del pensiero giuridico moderno, Milano, Giuffrè, XXXV, 2006.

HESPANHA, António Manuel. Razões de decidir na doutrina portuguesa e brasileira do séc. XIX: Um ensaio de análise de conteúdo. Quaderni Fiorentini per la storia del pensiero giuridico moderno, Milano, Giuffrè, v. 39, n. 1, p. 109-151, 2010.

HESPANHA, António Manuel. Cultura Jurídica Europeia: Síntese de um Mílénio. Coimbra: Almedina, 2017.

IHERING, Rudolf von. Teoria Simplificada da Posse. Tradução Fernando Bragança. Belo Horizonte: Editora Líder, 2004.

LARENZ, Karl. Metodologia da Ciência do Direito. Tradução José Lamego. 3. ed. Lisboa: Fundação Calouste Gulbenkian, 1991.

MATTOS, Ilmar Rohloff. O Tempo Saquarema (1986). 7. ed. São Paulo: Hucitec Editora, 2017.

MEIRA, Sílvio. Teixeira de Freitas: o jurisconsulto do Império. 2. ed. Brasília: Cegraf, 1983.

PETIT, Carlos. Derecho Civil e identidad nacional. Revista para el análisis del derecho, 
Barcelona, jul. 2011.

POUSADA, Estevan Lo Ré. Preservação da Tradição Jurídica Luso-Brasileira: Teixeira de Freitas e a Introdução à Consolidação das Leis Civis. Dissertação (Mestrado em Direito) - Faculdade de Direito, Universidade de São Paulo, São Paulo, 2006.

RANGEL, Alan Wruck Garcia O projeto de Teixeira de Freitas: um Código Civil Antinapoleônico? Contribuição ao Estudo do Comparatismo Jurídico no Século XIX. In: WAHLING, A.; SIQUEIRA, G.; BARBOSA, S. (org.). História do Direito: entre rupturas, crises e descontinuidades. Belo Horizonte: Arraes, 2018.

REIS, Thiago. Teixeira de Freitas leitor de Savingy. Research Paper Series - Legal Studies, n. 121 (FGV Direito), São Paulo, mar. 2015.

RÜCKERT, Joachim. O BGB - um código que não teve oportunidade? Revista da Faculdade de Direito da UFRGS, Porto Alegre, n. 34, p. 5-37, ago. 2016.

SAVIGNY, Friedrich Carl von. Das Recht des Besitzes. Viena: Druck und Verlag von Carl Gerold's sohn, 1865.

SAVIGNY, Friedrich Carl von. Sistema do direito romano atual. Tradução de Ciro Mioranza. Ijuí: Editora Unijuí, 2004. v. 8.

SCHIAVELLO, Aldo. Positivismo Jurídico e a Relevância da Metaética. In: DIMOULIS, Dimitri; DUARTE, Écio Oto (coord.). Teoria do Direito Neoconstitucional: superação ou reconstrução do positivismo jurídico? São Paulo: Editora Método, 2008.

SEELANDER, Airton Cerqueira-Leite. A longa sombra da casa. Poder doméstico, conceitos tradicionais e imaginário jurídico na transição brasileira do antigo regime à modernidade. Revista do IHGB, Rio de Janeiro, v. 178, n. 473, p. 327-424, jan./mar. 2017.

SIQUEIRA, Gustavo S. O Direito Civil antes do Código de 1916: a ausência das Ordenações Filipinas e as expectativas na imprensa e na doutrina nacional. Revista IHGB, Rio de Janeiro, v. 178, p. 545-562, jan./mar. 2017.

STAUT JUNIOR, Sérgio Said. Legisladores, juristas e os princípios jurídicos: quem tem o poder de direito em sociedade. Revista Jurídica Luso-Brasileira, Lisboa, v. 1, n. 5, 2015.

TEIXEIRA DE FREITAS, Augusto. Consolidação das Leis Civis (1857). 5. ed. anotada por Martinho Garcez. Rio de Janeiro: Jacintho Ribeiro dos Santos, 1915.

TEIXEIRA DE FREITAS, Augusto. Nova Apostilla à Censura do Senhor Alberto de Moraes Carvalho sobre o Projecto do Codigo Civil Portuguez. Rio de Janeiro: Typographia Universal Laemmert, 1859. 
TEIXEIRA DE FREITAS, Augusto Relatorios e pareceres dos membros da comissão encarregada de examinar o projecto do Codigo Civil do Imperio redigido pelo Bacharel Augusto Teixeira de Freitas. Rio de Janeiro: Typographia Nacional, 1865.

TEIXEIRA DE FREITAS, Augusto. Código Civil: esboço. Rio de Janeiro: Typ. Univ. Laemmert, 1860-1865.

TEIXEIRA DE FREITAS, Augusto. Código Civil: Proposta do Dr. Teixeira de Freitas sobre um novo plano para o mesmo Código Civil (1867). O Direito - Revista Mensal de Legislação, Doutrina e Jurisprudência, v. 24, n. 71, p. 321-328, 1896.

WALD, Arnoldo. A obra de Teixeira de Freitas e o Direito Latino-Americano. Revista de Informação Legislativa, Brasília, v. 41, n. 163, jul./set. 2004.

WEHLING, Arno; WEHLING, Maria José C. de. Formação do Brasil Colonial. Rio de Janeiro: Nova Fronteira, 1994.

WIEACKER, Franz. História do Direito Privado Moderno. Tradução António Manuel Hespanha. 2. ed. Lisboa: Fundação Calouste Gulbenkian, 1967.

\section{NOTA}

Quanto à contribuição de cada autora, temos a informar que Gabriela Back Lombardi fez coleta bibliográfica, análise e redação prévia e Fernanda Cristina Covolan fez coleta parcial de bibliografia, análise e redação final.

Como citar este documento:

LOMBARDI, Gabriela Back; COVOLAN, Fernanda Cristina. Direito Civil alemão no Brasil do século XIX: Teixeira de Freitas e a Escola Histórica alemã. Revista Opinião Jurídica, Fortaleza, v. 20, n. 33, p. 202-231, jan./abr. 2022. 